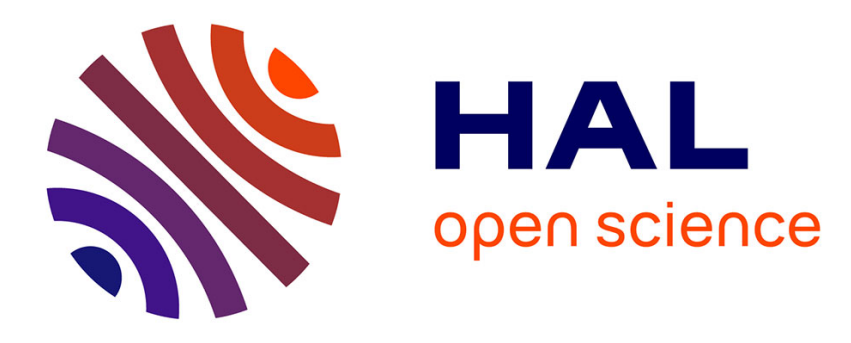

\title{
Soil micromorphological evidence of early agriculture in north-west Europe
}

R I Macphail, M A Courty, A. Gebhardt

\section{To cite this version:}

R I Macphail, M A Courty, A. Gebhardt. Soil micromorphological evidence of early agriculture in north-west Europe. World Archaeology, 1990, Soils and Early Agriculture, 22 (1), pp.53-69. 10.1080/00438243.1990.9980129 . hal-02275725

\section{HAL Id: hal-02275725 \\ https://hal.science/hal-02275725}

Submitted on 1 Sep 2019

HAL is a multi-disciplinary open access archive for the deposit and dissemination of scientific research documents, whether they are published or not. The documents may come from teaching and research institutions in France or abroad, or from public or private research centers.
L'archive ouverte pluridisciplinaire $\mathbf{H A L}$, est destinée au dépôt et à la diffusion de documents scientifiques de niveau recherche, publiés ou non, émanant des établissements d'enseignement et de recherche français ou étrangers, des laboratoires publics ou privés. 


\section{Soil micromorphological evidence of early agriculture in north-west Europe R. I. Macphail, M. A. Courty and A. Gebhardt}

\section{Introduction}

Various soil features, such as ard marks, spade marks, cultivation ridges, lynchets, and other colluvial deposits resulting from plough-wash, have been interpreted (Fowler and Evans 1967; Courty et al. 1989: 130 — 3, pl. IVg) as evidence of early agriculture. Other environmental information (such as snails, charred seeds, pollen) has also been used to support such interpretations. Soil micromorphology is another potential tool, one which can give great detail and thereby clarify field evidence. Also soil micromorphology can help establish a past record of cultivation where none is obvious in the field, and can often place such evidence into broader sequences, which may include phases of clearance, occupation, abandonment, and the regeneration ofnatural vegetation cover. In this paper we introduce the scientific basis of soil micromorphology and show, through experimental approaches and the study of archaeological sites, how it can be used to investigate soils and ancient agriculture.

Soil micromorphology, the microscopic study of soils in thin section, is based on the same principles as petrography. Unlike rocks or pottery, however, soils are unconsolidated and therefore it is necessary to take undisturbed samples carefully, sometimes supported by a metal box (Courty et al. 1989: 4\&3), to ensure that the arrangement of soil materials, sand, silt, clay and organic matter etc., and the gas/water spaces (voids: Bullock et al. 1985: 43-5), are preserved. Oven or acetone 'dried' soils are impregnated by resins (Murphy 1986: 55-64), which eventually permits a cured block to be cut up, and the slices to be mounted on glass and made into thin sections some 20-30 p.m thick, and up to $15 \times 7 \mathrm{~cm}$ in size. Such large thin sections can give a very good representation of a buried soil, especially when numerous sampling columns are taken across an old land surface. Problems of soil heterogeneity can be tackled in this way (Macphail, in press).

Soil micromorphology has developed its own complex descriptive terminology (Kubiena 1938; Brewer 1964; Bullock et al. 1985). Although used mainly in the study ofrecent soils, the technique has also been employed in the detection of ancient agriculture in soils buried beneath archaeological monuments (Cornwall 1958: 215; Manby 1963; Ashbee 1966; Romans and Robertson 1975; 1983). The interpretation of soil microfabrics is based on detailed pedogenic studies and on experiments on soils. Soil microfabrics are interpreted on a hierarchical basis, the effect of each soil process, including those relating to cultivation, being superimposed on, or disrupting earlier microfeatures (Bullock and Murphy 1979; Fedoroff 1982: 295-8; Courty et al. 1989: 138-9).

\section{Investigative approaches}

Before any micromorphological evidence of ancient agriculture can be recognized, it is necessary to understand both the character of the natural soil and the precise changes which result from disturbances. Experimental studies of undisturbed soils, and the changes consequent upon cultivation, are therefore necessary.

All human activity transforms the soil. The problem is to separate the effects of tillage from other forms of disruption, such as clearance of vegetation (see below) or trampling (Courty et al. 1989: 124). Modern agricultural science provides basic data on the differences between cultivated and non-cultivated soils, but other information can be obtained from simple experiments in 'ancient agriculture', mainly using non-mechanized tillage methods. The results from such experiments are, however, limited to the effects of generally short-term tillage. The effects of other transformations, relating to abandonment, revegetation and biological reworking, or burial, are not present. One major aim of the experiments reported here was to recognize features which could be used as indicators, and could be sought in archaeological soils. The aim was not, therefore, to reproduce exactly all the features which could be found in ancient cultivated soils; this would be impossible, in practical terms, since in all probability examples of undisturbed mid Holocene forest soils no 
longer exist. In fact, the full effect of tillage on 'ancient soils' has to be interpreted from the actual study of sites of prehistoric cultivation, and these also supply data on post-tillage soil transformations (Macphail, in press) and the effects of burial (Allen and Macphail 1987).

\section{Clearance features}

Clearance of vegetation is commonly considered a necessary precursor to cultivation, although this, as shown below for the Hambacher Forest experiment, is not always essential. No experimental soils data on clearance by ancient techniques is available, but the results of studies of soils affected by 'blow-downs', or tree-throw caused by high winds (Lutz and Griswold 1939; Denny and Goodlett 1956), and modern deforestation (Courty et al. 1989: 28\&9O) are accessible. In addition, microfabrics of asymmetrical subsoil hollow infills in palaeosols, interpreted as resulting from the toppling of large trees in prehistory (Macphail 1986: fig. 2; 1987; Macphail and Goldberg, in press) are also considered. The major features that result from this form of profile turbation are listed in Table 1. Ifa tree hollow is left to infill naturally, most of the microfabric heterogeneity may be homogenized by biological activity (Macphail 1987). Rapid burial by a monument, or through postclearance cultivation effects (burial and infilling by plough wash) may on the other hand allow this heterogeneity to be preserved, in the same way as pit and ditch fill microfabrics can be protected by dumping and sedimentation. Where young secondary woodland or shrubs are cleared, the impact on the soil profile is likely to be far less and therefore less readily recognizable in the field. The resulting heterogeneous microfabrics, characterized by dusty clay infills (Bullock ct al. 1985: 96), are, however, typical of disturbed soils (Macphail and Goldberg, in press), particularly when associated with indicators of vegetation burning (abundant charcoal fragments and phytoliths; Table 1). The in situ burning of toppled trees may permit areas of soil that are sufficiently strongly burned to be preserved as coarse red soil fragments. The presence of coarse wood charcoal in the surface horizons of a Neolithic soil buried by a barrow at Daladies, Angus, Scotland, led other workers (Romans and Robertson 1975) to infer 'slash and burn' clearance. Spontaneous fires could provide natural soil charcoal, but the natural burning of deciduous trees in the mid- to late Holocene of north-west Europe is thought unlikely.

\section{The effects of cultivation on soil microfabrics}

Much of our knowledge of the mieromorphology of cultivated soils comes from the work of Jongerius (1970: 1983) and Kooistra (1987), Some of the basic soil microfabric changes which occur in natural soils after they are cultivated are given in Table 2. Many of the large-scale changes and typical features occurring in modern cultivated soils relate to the effects of pressure and shear (and weight and vibration) caused by modern machinery. Such changes cannot be directly compared to those brought about by early cultivation. Nevertheless, those phenomena in modern cultivated soils which arise from the fact that, in comparison to natural vegetated soils, cultivated ones remain bare, or are irregularly protected, are the same. These phenomena are the breaking up and loss of structure of the surface soil aggregates under rain splash impact, and the consequent slaking and mobilization of water saturated soil. This is followed by washing and sedimentation; holes between tillage clods are infilled, and surface crusts (Plsl and 2) form (sometimes even between furrows), which may contain strongly oriented particles (Jongerius 1983; Boiffin and Bresson 1987). Trapped air often leads to the formation of vesicles in fully saturated horizons. These effects are also linked to changes in structural stability, in part governed by organic matter content, when forest and grassland are converted to arable use (Table 2; Imeson and Jungerius 1976; Grieve 1980). Soils that are puddlecl (Jongerius 1983: 113) through a combination of high moisture contents and trampling (e.g. by cattle) may also develop similar fabrics (Beckman and Smith 1974; Courty et al, 1989: 130). The pressure and shear forces produced by ancient tillage in soils where the moisture content is sufficiently high can also produce features indicating puddling and slaking ( $\mathrm{Pl}, 3)$.

Trapped water within the plough zone may also cause internal (subsurface) slaking. The soil separates and particles move downwards to become sorted or unsorted textural pedofeatures (Bullock et al. 1985: 109-115). Jongerius (1970) coined the term 'agricutan" for these coatings and 
infills that form down-profile as the result of surface or internal slaking. He noted that in light textured soils, these agricutans are mostly built up ofvarious silt and clay and impure clay (Bullock et al. 1985: 111, 114) layers, because of variations in sorting when all the components and size fractions of the ploughed horizon (Ap) are in movement after tillage disturbance. In heavier textured soils the coatings and infillings of voids are homogeneous, and principally made up of clay and microscopic fragments of organic matter and opaque material; hence the term 'dusty clay' (Pls 4, 5 and 6). In contrast, 'limpid clay' coatings (Bullock et al. 1985: 111, 114) are more generally associated with weathering, and clay translocation in alfisols (Soil Survey Staff 1975) under undisturbed broadleaved woodland (Fedoroff and Goldberg 1982). In undisturbed alfisols these coatings are generally absent from surface horizons because of the homogenizing effect of biological activity, but they accumulate in the subsoil.

Tillage also leads to the mixing of soil material and to the washing of pieces of plough soil down cracks in the profile (Jongerius 1970; 1983). The physical action of tillage results in smaller aggregates accumulating, and void space diminishing, at the base of the plough zone (see $\mathrm{Pl} .12$ ), whereas large aggregates and coarse voids concentrate near the surface (Dexter 1976; 1979).

\section{Experiments in 'ancient agriculture'}

The microfabrics of four uncultivated soils were compared with those that developed after cultivation by hoe, ard, spade and motor-cultivator (Gebhardt, in press). Exact replication of ancient tillage methods, crops, or soil types was not possible, but as stated earlier, this was not believed to be critical for these experiments. Such experiments, however, cannot be carried out just anywhere, and so two sites with well-documented land use and soil characteristics at the modern experimental farm of Grignon, Yvelines, France (lnstitut National Agronomique), namely the Grignon forest and Dehérain plots (Morel et al. 1984), and two 'ancient farms' (Butser Hill, Hampshire, England: Reynolds 1981; and Hambacher Forst, Elsdorf, Rhinelands, Germany: Lüning and Meurers-Balke 1980; Meurers-Balke 1985) were selected (Table 3). Thus in this preliminary series of soil micromorphological experiments in 'ancient agriculture', both the parent materials and soil types (cambisols and alfisols: Soil Survey Staff 1975) at the 'ancient farms' were replicated at a soil science establishment. Sampling for micromorphology took place either immediately or a few days after tillage, using three or four tin monoliths and extending to depths of $30-50 \mathrm{~cm}$. Virgin or uncultivated surface horizons, and sometimes their subsoils (e.g. at Hambacher Forest), were similarly sampled.

The uncultivated soils are rather compact with good subangular blocky structures, except for the Hambacher soil which was very weakly structured because of its fine sandy/coarse silty texture. The Deherain soil is the most open structured (Pl. 7). All, however, are characterized by large amounts of included organic matter, and biological activity, which are responsible for the intra-pedal porosity. In all cases cultivation led to the soil becoming looser, through an 'explosion' of fine structures (Pl. 8) which relates to inherent weaknesses in soil peds caused by wetting and drying. These weaknesses fractured under cultivation impact, a phenomenon also known from modern agriculture. The size of the newly-formed structures reflects the nature of the cultivation implement: medium angular peds, Butser (ard); coarse angular peds, Deherain (spade). Cultivation by motor cultivator at Dehérain also led to the smaller peds concentrating at around $10-20 \mathrm{~cm}$ depth to produce a weakly compacted layer. Manured cultivation soils at Butser and Dehérain showed enhanced structural stability and biological activity. As a result, continuing good structural development at Butser, even after tillage, made it difficult to ascertain the depth limit of ard cultivation, but the more coarse effects of spade cultivation at Dehérain was established down to $12 \mathrm{~cm}$. No depth limit to hoeing was recognized at Grignon Forest, because of structural instability (see below). At all the sites the nature of the uncultivated soil could often be recognized as humic soil fragments within the biggest clods, but the increase in porosity and numbers of structures is far more poorly expressed in the lighter textured soils at Grignon and Hambacher Forest. 
For example, hoeing at Grignon Forest was accompanied by intensive watering, which eventually resulted in structural collapse. At Hambacher Forest the cultivated soil contains numerous rounded peds of humic topsoil and more mineral subsoil. In these weakly structured soils, the peds were apparently compacted into the loose soil matrix by ard tillage. At around $6 \mathrm{~cm}$ depth, at the base of the tilled soil at Hambacher Forest, a lcm thick weakly-compacted silt pan formed, and at about 12$14 \mathrm{~cm}$ depth some dusty clay accumulated. The latter was superimposed over limpid clay coatings that characterize the uncultivated 'forest' soil.

\section{Data from ancient cultivated soils}

Only a few archaeological sites with independent (non-pedological) evidence of cultivation have been investigated by soil micromorphology. The examples cited (Table 4) provide the best range available of microfabrics resulting from cultivation activity, varying according to topography, parent material and soil type. Soil texture strongly influences the fabric type, structure and tcxtural features that result from cultivation (Jongerius 1970), and so the examples are ordered from the coarsest soils to the finest. In the examples, the ancient cultivated soils were well sealed by a number of agencies, both natural (alluvium at Phoenix Wharf and blown sand at Lodbjerg) and human (colluvium at Ashcombe, walls at Le Wasserwald and a long barrow at Kilham). Any investigation of ancient soils should ascertain the degree of preservation, and soil micromorphology is probably the best technique for making this estimation. For example, biological reworking by earthworm or root penetration through the overburden, can be readily recognized, and alteration of organic matter and some other bio-chemical effects can also be identified (Macphail 1986: 269-70; Allen and Macphail 1987). In fact, sampling upwards into the colluvium or mound above a buried landsurface is common practice; for instance, to make sure that clay coatings within the surface of a buried soil have not come from the construction of an archaeological structure (Romans and Robertson 1983). The identification of post-cultivation events, such as abandonment or occupation before burial, can be made through the analysis of microfeatures on an hierarchical basis. At Phoenix Wharf, London (Table 4), where ardmarks were interpreted, the buried plough soil comprises sand grains coated by a fine fabric of silt and organic matter (see Table 2; Pls 9 and 10). The underlying sand contains downwashed fine material, but because of the total absence of clay this subsoil has only rare and poorly formed coatings. On the more coarse windblown sands at Lodbjerg, west coast of Jutland (Courty and Nornberg 1985), tillage (ardmarks) produced an Ap horizon similar to that of Phoenix Wharf, but no subsoil features. There is good organic matter preservation of the fine fabric at both sites through waterlogging (Phoenix Wharf) and acidity (Lodbjerg). This may help account for the well developed Ap horizons, which are much thicker than the $6 \mathrm{~cm}$ depth impact of ard tillage. Also, plough soil accretion has been enhanced at the sites by alluviation and sand blowing, respectively, and the additional presence of much domestic waste may indicate manuring of the cultivation soils as well.

Pollen analysis of the soil buried under the cairn at Chysauster, Cornwall (Scaife pers. comm.) shows a phase of woodland clearance, followed by cultivation and soil acidification. The turbated subsoil microfabric (Table 4) is good evidence of woodland clearance. This clearance probably reduced both the earthworm population and the stability of the topsoil and, with cultivation, may have led to surface soil acidification. The later Iron Age field systems at Chysauster are characterized by well developed lynchets, and within these colluvial deposits are a number of fragmented crusts and coatings, consistent with surface and internal slaking in cultivated soils (Jongerius 1970, 1983); these indicators have been preserved by podzolic cementation. The colluvium also contains rounded soil fragments, both of the relict brown subsoil and the contemporary podzol cover, as evidence of the widespread and deep erosive effects of long term cultivation.

Sampling of the soil outside the ancient field system at Le Wasserwald (Bas-Rhin, France) found only limpid clay void coatings, indicating the earlier presence of a forest cover in the area. In contrast, Gallo-Roman cultivation, as evidenced by plough marks cutting into the sandstone parent material, seems to have led to an accumulation of fine fabric at the soil surface. Translocation of 
coarse soil, similar to agricutans (Jongerius 1970) was confined to the cultivated area, and was found to be superimposed over the limpid clay coatings. On the somewhat finer terrace alluvium at Strathallan, Perthshire, local pollen and field features ('cultivation ridges') suggested Neolithic cultivation (Barclay 1983). Semi-quantitative numerical analysis of the vertical distribution of textural features was carried out on soils beneath the henge, and through the mound (see Pl. 4) and buried soil of the barrow site, including samples through the 'cultivation ridges' (Romans and Robertson 1983). The highest concentrations of textural pedofeatures were found near the soil surface $(4-5 \mathrm{~cm})$ of the cultivation ridges under the barrow mound, whereas under the henge the greatest concentration of textural features was around 12cm depth. Romans and Robertson (1983) thought that the greatest concentration of textural features would reflect the soil depth most disturbed by shear and pressure forces produced by the impact of the tillage implement; they inferred, therefore, that there had been shallow hoeing of the 'cultivation ridges' at the mound site, and deeper ard tillage in the area of the henge. The lack of earthworm fabrics and the low organic status of the buried soils (even after post-burial oxidation was taken into account) indicated to Romans and Robertson that Neolithic cultivation had led to a diminution of soil organic matter, resulting in poorly stable soils (Courty et al. 1989: plate IVe).

A land-use history comprising two cultivation phases separated by a period of stable grassland was inferred from soil pollen in the shallow $(20 \mathrm{~cm})$ soil under the Neolithic long barrow at Kilham, Yorkshire (Dimbleby and Evans 1974). The microfabric comprises a partially homogenized soil, with root channels coated by dusty clay (see Pl 5 and 6). These features may reflect either a later land-use history of grassland followed by cultivation (as inferred from the pollen), or that the root channels were the result of crop growth and were coated by the effects of continuing tillage. On similar, but colluvial, silt loam parent materials in the dry valley at Ashcombe Bottom, Sussex, Beaker period cultivation was apparently recorded by ardmarks (Allen 1984). The plough soil colluvium contains rounded soil fragments eroded from the relict alfisol cover that had formed from the weathered chalk and 'Clay-with-Flints'. Also pieces of clay rich crust and associated charcoal (see Plates 1 and 2), presumably resulting from the surface slaking of alfisol material in cultivated soils, were mixed into the Ap horizon by later tillage and colluviation. Some compact soil areas of the upper plough soil were characterized by planar voids (shear planes: see Pl. 3), presumably from 'plough' shear. In addition, the dense prismatic structures were broken up in places into finer subangular blocky structures by the impact of tillage, and biological activity has been concentrated in these more open soil areas (Pl. 11). In contrast, towards the base of the plough soil, the soil is much more compact, with textural features (Plate 12) indicating that the resulting poorer drainage encouraged internal slaking.

\section{Discussion}

The identification and interpretation of ancient cultivated soils requires the differentiation of precultivation features from those generated by the phase or phases of agriculture itself, and those caused by later events such as abandonment and burial. In the analysis of soil thin sections, relict late glacial features may have to be considered separately before early Holocene forest soil (alfisol) formation (e.g the limpid clay at Le Wasserwald) can be interpreted. Similarly, the turbating effects on the soil of shrub, scrub or forest clearance will need to be discriminated from later mixing by cultivation. For example, at Neolithic Maiden Castle, Dorset, and Beaker period Brean Down, Somerset (Macphail and Goldberg in press), vertical sampling of buried soils produced evidence of soil disruption at the base of the soil profiles which pre-dated microfabrics consistent with the effects of cultivation. This succession of features clearly indicated that woodland clearance preceded agricultural activity. Some workers (Liming and Meurers-Balke 1980; Meurers-Balke 1985; Romans, pers. comm), however, have suggested that Neolithic farmers did not necessarily clear the land of trees, but ploughed between them.

It is evident that soils will respond differently to tillage according to their texture, base status, original organic matter content and levels of biological activity. As predicted by Jongerius (1970; 1983), sands will lose their weak structures and these will be replaced by various intergranular fine 
fabrics; such effects are seen in the buried soils at Lodbjerg, Phoenix Wharf (Pls 9 and 10) and Le Wasserwald. The low pedality of silt loam soils can lead to loss of structure (as at Grignon Forest) and to weakly compacted pan formation (as at Hambacher Forest). The finer, high base status soils at Butser and Dehérain reacted to tillage by an explosion offine structures (Pls 7 and 8), that were generally stable, especially where manuring had enhanced levels of organic matter and biological activity. This break-up of coarse structures by tillage was found at Ashcombe (Pl.11), as was the movement down profile of fine soil peds (as noted at Dehérain), although the poorer structural stability at Ashcombe led to compaction (Pl. I2). At Strathallan the soils readily slaked (Pl. 4) under the impact of tillage, with supposed ard cultivation causing the concentration of textural features at 12cm (Romans and Robertson 1983). The actual depth limit of ard tillage at Hambacher Forest was only $6 \mathrm{~cm}$, but dusty clay coatings resulting from this cultivation were accumulating at $12-14 \mathrm{~cm}$. The abundant presence of dusty clay coatings in voids in upper soil horizons beneath the Neolithic long cairn at Hazleton, Gloucestershire, (Saville 1984; Macphail etal. I987: figs. 7 and 8), has been used to infer cultivation on this site. As at Strathallan, the impact of tillage on soils with poor structural stability is thought to have caused slaking and the development of textural features. One reason for this poor structural stability could be lack of organic matter. At both sites earthworm activity, which is abundant in the surface horizons of uncultivated forest soils, is very low, and may be another reflection of the low organic matter levels that could have resulted from early cultivation practices. At Phoenix Wharf and Lodbjerg, manuring was inferred, and at Hazleton it was noted that the final phase of cultivation either moved to a domestic refuse-rich midden area (Macphail, in press), or that manuring was undertaken. Beneath the immediate surface horizons of the buried soils at Maiden Castle, Hazleton and Kilham, biological features (peds or root channels) were found to be coated with dusty clay (Pls 5 and 6), indicating that during ancient agriculture, biological activity (e.g. rooting by crops/weeds; faunal working) could accompany the effects of surface soil slaking and down profile soil translocation, induced by tillage. At Chysauster, on the other hand, clearance and tillage led to a decrease in the earthworm population through acidification. Lastly, changes in the soil landscape may also be inferred from eroded soil fragments in colluvial ploughsoil deposits, as at Ashcombe Bottom and Chysauster.

Obviously, the best examples of ancient cultivated soils are those buried soon after being used for agriculture. If the cultivated soil is abandoned but, before burial, an herbaceous cover develops, or shrubs invade (Macphail in press), or the land is given over to pasture, earthworms will eventually rework it. In addition, tilled soils can be trampled and mixed by domestic occupation, or partially eroded. All these post cultivation events blur or totally remove the agricultural history from the soil. Post-burial effects have also to be considered (Courty et al. 1989: 140-6).

\section{Conclusion}

In the study of ancient cultivated soils, microfabrics have to be studied on an hierarchical basis, so that agricultural features can be distinguished from those of the natural soil. Modern agricultural science has provided a data base for these investigations, but experiments in 'ancient agriculture', especially when combined with empirical studies of ancient sites, have been important in permitting the mechanisms involved in tillage to be better understood. Significantly, this success has occurred in spite of experimental problems with replicating the exact tillage method, crop or soil type which existed in the past. Now that some of the physical mechanisms are understood, it is possible to identify microscopic fabric, structural and textural indicators of ancient agriculture, although these vary according to soil type, grain size, organic matter content and base status. It is the combination of indicators that is important, so that, for example, 'agricutans' should not be regarded on their own as categorical evidence of cultivation.

\section{Acknowledgements}

The authors are very grateful for an 'Action Thematique Programmee' grant from the CNRS, France; the support of English Heritage; and the co-operation of the many directors of the experimental farms and archaeological sites discussed in this study. 


\section{References}

Allen, M. J. 1984. Ashcombe Bottom Excavation AB84. Lewes: Lewes Archaeological Group. Allen, M. J. and Macphail, R. I. 1987. Micromorphology and magnetic susceptibility studies: their combined role in interpreting archaeological soils and sediments. In Soil Micromorphology (eds N. Fedoroff, L. M. Brcsson, and M. A. Courty). Plaisir: AFES, pp. 66946.

Ashbec, P. 1966. The Fussclls Lodge long barrow excavations 1957. Archaealogia, 100: 1-8O. Barclay, G. T. 1983. Sites of the third millennium BC to the first millennium AD at North Mains, Strathallan, Perthshire. Proceedings Society Antiquaries Scotland, 113: 122-281.

Beckman, G. G. and Smith, K. J. 1974. Micromorphological changes in surface soils following wetting, drying and trampling. In Soil Microscopy (ed. G. K. Rutherford). Kingston, Ontario: The Limestone Press, pp. 83245.

Boiffin, J. and Bresson, L. M. 1987. Dynamique de formation des routes superficielles: rapport de l'analyse microscopique. In Soil Micromorphology (eds N. Fedoroff, L. M. Bresson and M. A. Courty). Plaisir: AFES, pp. 393 99.

Brewer, R. I964. Fabric and Minera/Analysis ofSoil.s'. New York: Wiley \& Sons.

Bullock, P. and Murphy, C. P. 1979. Evolution of a palaeo-argillic brown earth (Paleudalf) from Oxfordshire, England. Geoderma, 22: 225-52.

Bullock, P., Fedoroff. N., Jongerius, A. , Stoops, G. , and Tursina, T. 1985. Handbookfor Soil Thin Section Description. Wolverhampton: Waine Research Publishers.

Cornwall, I. W. 1958. Soilsfor the Archaeologist. London: Phoenix I-louse.

Courty, M. A. and Nornberg, P. 1985. Comparison between buried uncultivated and cultivated Iron Age soils on the west coast of Jutland, Denmark. In Proceedings ofthe Third Nordic Conference on the Application of Scientific Methods in Archaeology (eds H. Jungner and T. Edgren). Helsinki: Finnish Antiquarian Society (ISKOS 5) pp. 57-70.

Courty, M. A., Goldberg, P., and Macphail, R. I. 1989. Soils andMicromorphology inArchaeology. Cambridge: Cambridgc University Press.

Denny, C. S. and Goodlett, J. C. 1956. Microrelief resulting from fallen trees. In Surficial Geology and Geomorphology of Potter County, Pennsylvania (ed. C. S. Denny). US Geological Survey Professional Paper 288: 59\%5.

Dexter, A. R. 1976. Internal structure of tilled soil. Journal ofSoil Science, 27: 267-278.

Dexter, A. R. 1979. Prediction of soil structures produced by tillage. Journal of Terrarnechanics, 16(3); 117-127.

Dimbleby, G. W. and Evans, J. G. 1974. Pollen and land snail analysis of calcareous soils. Journal of Archaeological Science, 1: 1, 17-33.

Fedoroff, N. 1982. Soil fabric at the microscopic level. In Constituents and Properties ofSoils (eds M. Bonneau and B. Souchier). London: Academic Press, pp. 288-303.

Fedoroff, N. and Goldberg, P. 1982. Comparative micromorphology of two late Pleistocene paleosols (in the Paris Basin). Carena, 9(3/4): 227-51.

Fowler, P. J. and Evans, J. G. 1967. Plough marks, lynchcts and early fields. Antiquity, 41: 289-301. Gebhardt, A. In press. Micromorphological analysis of structural modifications caused by different cultivation implements. In L'ExpIoitation des Plantes en Prehisloire: Documents et Techniques. Actes dc la Table Ronde CNRS, des14-17juin, 1988.

Grieve, I. C. 1980. Some contrasts in soil development between grassland and deciduous woodland sites. Journal ofSoil Science, 31: 13745.

Imcson, A. C. and Jungerius, P. D. 1976. Aggregate stability and colluviation in the Luxembourg Ardennes: an experimental and micromorphological study. Earth Surface Processes, I: 259271. Jongerius, A. 1970. Some morphological aspects of regrouping phenomena in Dutch soils. Geoderma, 4: 311 31.

Jongerius A. 1983. Micromorphology in agriculture. In Soil Micromorphology (eds P. Bullock and C. P. Murphy). Berkhamsted: A B Academic Publishers, pp. 111-38.

Kooistra, M. J. I987. The effects of compaction and deep tillage on soil structure in a Dutch sandy loam soil. In Soil Micromorphology (eds N. Fedoroff, L. M. Bresson, and M. A. Courty). Plaisir: 
AFES pp. 445-450.

Kubiena, W. L. 1938. Micropedology. Ames, Iowa: Collegiate Press Inc.

Liming. J. and Meurers-Balkc, J. 1980. Experimentellcr Getreidcanbau im Hambacher Forst, Gemeinde Elsdorf. Kr. Bergheim/Rheinland. Sonderdruck aas Bonner Jahrbiicher, 180: 30544. (Rheinischen Landesmuseums in Bonn.)

Lutz, H. J. and Griswold. F. S. 1939. The influence of tree roots on soil morphology. American Journal Science, 237: 389-400.

Macphail. R. I. 1986. Paleosols in archaeology: their role in understanding Flandrian pedogenesis. In Paleosols (ed. V. P. Wright). Oxford: Blackwells Scientific Publications, pp. 263-290.

Macphail, R. I. I987. The soil micromorphology of tree subsoil hollows. Circaea, 5, 1: 14-17.

Macphail, R. I. In press. The soils. In Hazleton North, Gloucestershire, 1979-82: The excavation ofa

Neolithic long cairn of the Cotswold-Severn group (ed. A. Saville). London: English Heritage.

Archaeological Report 13, pp. 225-8.

Macphail, R. I. and Goldberg, P. In press. The micromorphology of tree subsoil hollows: their significance to soil science and archaeology. In Soil Micromorphology (ed. L. A. Douglas). Elsevier Press: Amsterdam.

Macphail, R. I., Romans, J. C. C., and Robertson, L. 1987. The application of soil

micromorphology to the understanding of Holocene soil development in the British Isles; with special reference to early cultivation. In Soil Micromorphology (eds N. Fedoroff, L. M. Bresson and M. A. Courty). Plaisir: AFES, pp. 647-56.

Manby. T. G. I963. The excavation of Willcrby Wold long barrow, East Riding, Yorkshire. Proceedings Prehistoric Society, 29: 173-203.

Meurers-Balke, J. 1985. Experiments zum Anbau und zur Verarbciterung priihistoriseher Getreidcarten. Archiiologische Information, 8(1): 8-17.

Morel, R.. Lasnier, T. and Bourgeois, S. 1984. Les essais defertilisation de longue durée de la station agronornique de Grignon. Disposif Dehérain et des 36 parcelles. Resaltats experimentaax (periode 1938-1982). Paris-Grignon: INRA.

Murphy, C. P. I986. Thin section preparation ofSoils and Sediments. Berkhamsted: A B Academic Publishers.

Reynolds, P. J. I981. Deadstock and livestock. In Farming Practices in British Prehistory (ed. R. Mercer). Edinburgh: Edinburgh University Press, pp. 97 12Z.

Romans', J. C. C. and Robertson, L. 1975. Soils and archaeology in Scotland. In The Effects ofMan on the Landscape: the Highland Zone (eds J. G. Evans. S. Limbrey, and H. Cleere). London: CBA Research Report 11, 37-9.

Romans, J. C. C. and Robertson, L. 1983. The general effects of early agriculture on the soil. In The Impact of Aerial Reconnaissance on Archaeology (ed. G. S. Maxwell). London: CBA Research Report 49. 136-41.

Saville, A. I984. Preliminary report on the excavation of a Cotswold-Severn tomb at Hazleton, Glouccstershire. Antiquaries Journal, 64: 10—24.

Soil Survey Staff, 1975. Soil Taxonomy. A basic system of soil classification for making and interpreting soil surveys. Agricultural Handbook 436. Washington DC: USDA.

\footnotetext{
Abstract

Macphail, R. I., Courty, M. A., and Gebhardt, A.

Soil micromorphological evidence of early agriculture in north-west Europe The study of early agricultural soils using micromorphology is outlined. The effects of tillage due to modern agriculture are reviewed and the results from four experiments in 'prehistoric cultivation' are presented. These are used in the interpretation of prehistoric agricultural practices, based on a study of soils from various archaeological sites in north-west Europe. It is suggested that microfabric features, varying according to soil texture, can be diagnostic of tillage. Microfabric type, textural features (e.g. coatings) and structure are, taken together, better indicators of ancient tillage than single features.
} 
Table 1 Microfabrics associated with vegetation clearance: a summary of the field and micromorphological evidence.

Forest and scrub:
$\begin{aligned} & \text { Possibility of subsoil hollows with asymmetric soil infill (tree toppling); moderately deep (2O-4Ocm) to deep ( } 40-100 \mathrm{~cm}) \text { soil mixing }- \\ & \text { juxtaposed topsoil and subsoil fragments, with fissures infilled by dusty clay; clay coatings, if present in subsoil (Bt horizon) fragments. are often } \\ & \text { unoriented to present soil surface; coarse wood charcoal often present; possibility of burned red soil with strongly enhanced magnetic susceptibility. }\end{aligned}$
$\begin{aligned} & \text { Low shrubs: } \\ & \text { Shallow (I)-20cm) soil mixing; coarse voids infilled by dusty clay or surface soil material; fine } \\ & \text { charcoal often present; possibility of many phytoliths. }\end{aligned}$

Table 2 Changes in microfabric when soils previously under natural vegetation were cultivated by modern methods.

\begin{tabular}{|c|c|c|c|}
\hline \multirow[t]{2}{*}{ Previous vegetation } & \multirow[t]{2}{*}{ Soil/parent material } & \multicolumn{2}{|l|}{ MicrofabricCultivated } \\
\hline & & Natural & Cultivated \\
\hline Forest & $\begin{array}{l}\text { Alfisol (argillic Spongy Compact } \\
\text { aggregate brown earth) } \\
\text { Loess }\end{array}$ & Spongy & Compact aggrégate \\
\hline Forest & $\begin{array}{l}\text { Spodosol (podzol) } \\
\text { Sand }\end{array}$ & Crumb or pellety moder & $\begin{array}{l}\text { Skeleton grain coatings of } \\
\text { disintegrated pellety material }\end{array}$ \\
\hline Grassland & $\begin{array}{l}\text { Cambisol (brown earth) } \\
\text { Silt loam }\end{array}$ & $\begin{array}{l}\text { Very dark stable crumb or granular } \\
\text { aggregates and very high interpedal } \\
\text { porosity }\end{array}$ & $\begin{array}{l}\text { Structure degrades, faunal activity } \\
\text { and } \\
\text { organic matter decreases. Compact } \\
\text { apedal, weak angular blocky } \\
\text { structure }\end{array}$ \\
\hline
\end{tabular}

Table 3 Sites of experiments in 'ancient agriculture".

\begin{tabular}{|c|c|c|c|c|}
\hline Site & Parent material/soil type & Vegetation & Tillage method & Crop \\
\hline $\begin{array}{l}\text { Dehérain } \\
\text { Experimental Farm, } \\
\text { France }\end{array}$ & $\begin{array}{l}\text { Calcareous colluvium } \\
\text { Cambisol (brown earth) }\end{array}$ & Grassland (sampled) & Spade, motor-cultivator & $\begin{array}{l}\text { No crop, but, history of } \\
\text { cropping. } \\
\text { Manured and non-manured } \\
\text { areas sampled }\end{array}$ \\
\hline $\begin{array}{l}\text { Butser Hill 'Iron Age } \\
\text { Farm' England }\end{array}$ & $\begin{array}{l}\text { Calcareous colluvium, } \\
\text { Cambisol (brown earth) }\end{array}$ & Grassland (sampled) & Ard & $\begin{array}{l}\text { No crop but, history of } \\
\text { cropping. } \\
\text { Manured and non-manured } \\
\text { areas sampled }\end{array}$ \\
\hline $\begin{array}{l}\text { Hambacher Forst } \\
\text { 'Neolithic Farm', } \\
\text { Germany }\end{array}$ & $\begin{array}{l}\text { Loessic loam Alfisol } \\
\text { (argillic brown earth) }\end{array}$ & $\begin{array}{l}\text { Broadlcaved forest } \\
\text { (sampled) }\end{array}$ & $\begin{array}{l}\text { Ard; criss-cross ploughing } \\
\text { between trees several times } \\
\text { in one year }\end{array}$ & $\begin{array}{l}\text { No crop; no clearance, only } \\
\text { trccs removal of leaf litter }\end{array}$ \\
\hline $\begin{array}{l}\text { Experimental Grignon } \\
\text { Forest }\end{array}$ & $\begin{array}{l}\text { Loessic loam, Alfisol } \\
\text { (argillic brown earth) }\end{array}$ & $\begin{array}{l}\text { Broadleaved forest } \\
\text { (sampled) }\end{array}$ & Hoe & No crop or clearance. \\
\hline
\end{tabular}

Table 4 Micromorphological features of ancient cultivated soils.

\begin{tabular}{|l|l|l|}
\hline Site/period & Soil/parent material & Microfeatures \\
\hline Lodbjerg, Denmark (coast) Iron Age & Haplohumod (podzol) Coastal aeolian sand & $\begin{array}{l}\text { 20cm thick grey homogeneous Ap of open } \\
\text { packing sand with thin darkish brown coatings }\end{array}$ \\
\hline
\end{tabular}




\begin{tabular}{|c|c|c|}
\hline & & $\begin{array}{l}\text { and few dark brown aggregates rich in charred } \\
\text { organic matter fragments and phytoliths. } \\
\text { Subsoil (A2) totally clean sand. }\end{array}$ \\
\hline $\begin{array}{l}\text { Phoenix Wharf, England (alluvial plain) } \\
\text { Early Bronze Age }\end{array}$ & $\begin{array}{l}\text { Psammaquept (ground water gley) Alluvial silt } \\
\text { over sand }\end{array}$ & $\begin{array}{l}\text { 17cm thick Ap comprising clean sand and fine } \\
\text { fabric of silt, dark brown plant fragments and } \\
\text { amorphous organic matter. Charcoal and } \\
\text { phytoliths present. Fine fabric contains very } \\
\text { little clay and forms grain coatings and void } \\
\text { infills. Subsoil is clean sand with inwashed Ap } \\
\text { material and rare poorly oriented coarse and } \\
\text { dusty clay coatings. }\end{array}$ \\
\hline Chysauster, England (upland) Bronze Age & Haplorthod (podzol) Granitic loamy sand & $\begin{array}{l}\text { Buried soil beneath cairn: at 2(P30em broken } \\
\text { peds separated by inwashed impure and dusty } \\
\text { clay indicating clearance. Diminishing } \\
\text { earthworm population - originally acid } \\
\text { cambisol (brown earth) - and development of } \\
\text { easily slaked topsoil. } \\
\text { Later (Iron Age?) field system: in lynchets } \\
\text { pan-like layers of fine charcoal, dusty clay } \\
\text { coatings and infills - now ferruginized, and } \\
\text { rounded fragments of both relict subsoil and } \\
\text { Bh horizon material. }\end{array}$ \\
\hline $\begin{array}{l}\text { Le Wasserwald, France (upland) Gallo- } \\
\text { Roman }\end{array}$ & $\begin{array}{l}\text { Psammalf (argillic brown sand) Sandstone, } \\
\text { loamy sand }\end{array}$ & $\begin{array}{l}\text { Concentration of fine fabric in top few cm. } \\
\text { Primary phase of limpid clay coatings (original } \\
\text { forest vegetation) is followed by impure clay } \\
\text { coatings. }\end{array}$ \\
\hline $\begin{array}{l}\text { Strathallan, Scotland (river terrace) } \\
\text { Neolithic }\end{array}$ & $\begin{array}{l}\text { Alfisol (argillic brown } \\
\text { earth) alluvial silty clay } \\
\text { loam }\end{array}$ & $\begin{array}{l}\text { Buried soil under mound: abundant silt and } \\
\text { clay coatings in top } \mathrm{O}-5 \mathrm{em} \text { (cultivation } \\
\text { ridges). } \\
\text { Buried soil beneath henge: silt and clay, dusty } \\
\text { clay coatings concentrated at } 12 \mathrm{~cm} \text { depth. } \\
\text { In subsoils further accumulations of clay } \\
\text { coatings at } 40 \text { - } 60 \mathrm{Cm} \text { depth. }\end{array}$ \\
\hline Kilham, England (downland) Neolithic & $\begin{array}{l}\text { Alfisol (argillic brown } \\
\text { earth) silt loam over } \\
\text { chalk }\end{array}$ & $\begin{array}{l}\text { Many dusty clay coatings in base of the } 20 \mathrm{~cm} \\
\text { thick soil — some lining obvious root holes. }\end{array}$ \\
\hline Ashcombe, England (dry valley) Beaker & $\begin{array}{l}\text { Cambisol (brown } \\
\text { earth) silt loam } \\
\text { colluvium over chalk }\end{array}$ & $\begin{array}{l}\text { Accretionary soil contains common rounded } \\
\text { fragments of relict alfisol cover, and slaked } \\
\text { alfisol material (surface crust?). Few dusty } \\
\text { coatings and infills occur, but many weak } \\
\text { intercalations are present within prisms. Dense } \\
\text { prismatic structures are juxtaposed to open } \\
\text { areas of fine peds. Porosity increases upwards, } \\
\text { towards ephemeral colluvial soil surface scored } \\
\text { by ard marks. }\end{array}$ \\
\hline
\end{tabular}

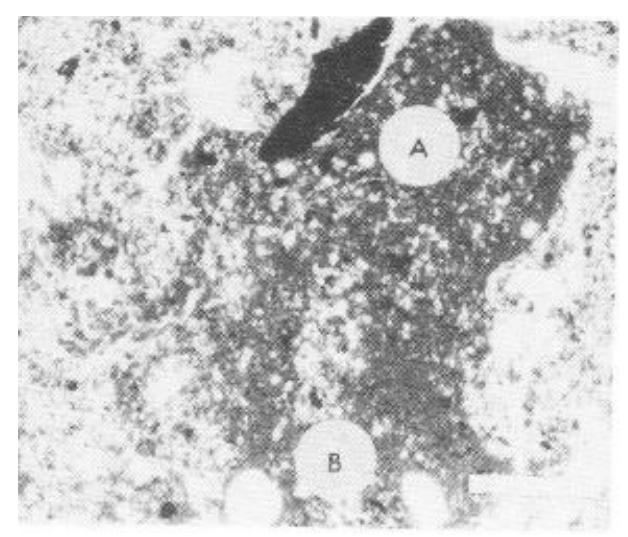

Plate 1 Ashcombe Bottom 1984: cultivation colluvium with probable fragment old surface crust (A) formed out of clay-rich soil derived from the reliet alfisol cover. A coarse piece of charcoal has been included in soil that hasbecome completely slaked, giving rise to vesicles (B) resulting from trapped air. Plane polarized light (PPL); scale $=0.9 \mathrm{~mm}$. 


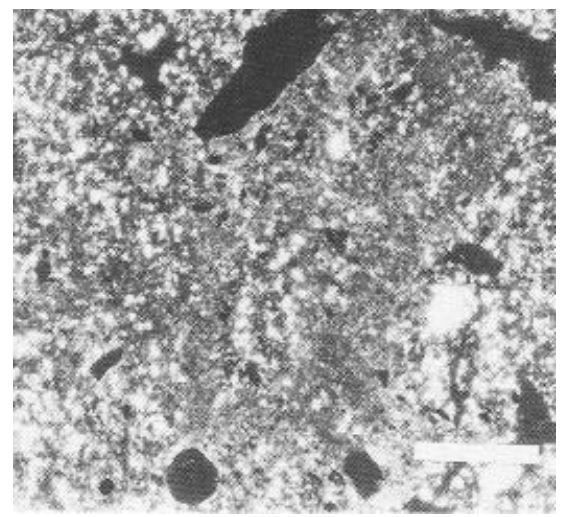

Plate 2 As Plate l. but observed under crossed polarized light (XPL). Note birefringence of clay crust. especially where clay has become oriented around the vesicles. Scale $=0.9 \mathrm{~mm}$.

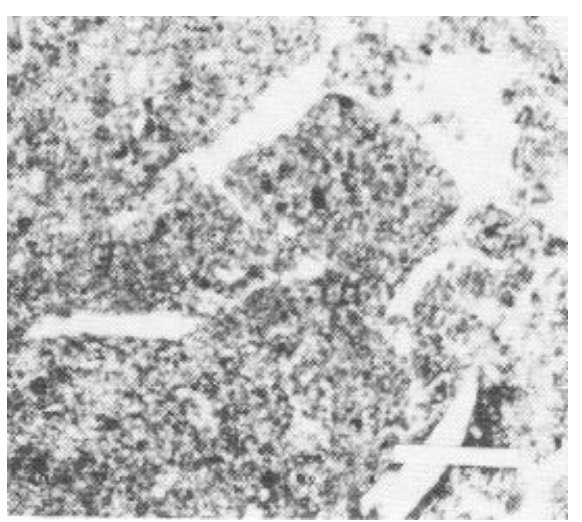

Plate 3 Ashcombe Bottom 1984: dense silt loam cultivation eolluvium, with parallel-sided, straightedged planar voids (shear planes) pro- duced by tillage implement (ard) impact. PPL; scale = $0.9 \mathrm{~mm}$.

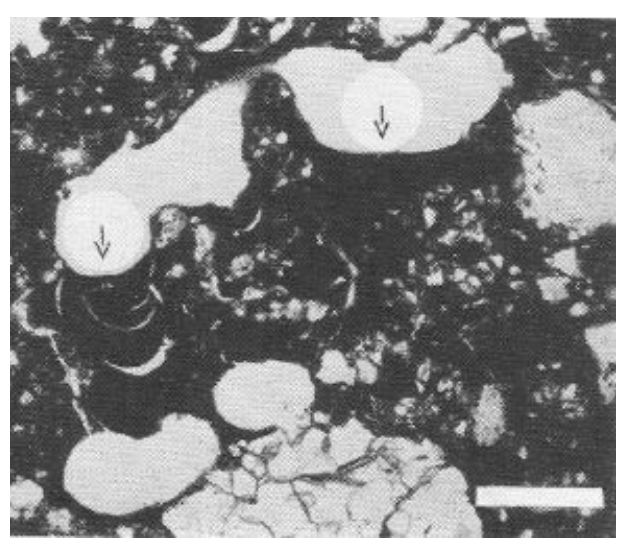

Plate 4 Strathallan Mound 1983: turf mound contains very fragile Neolithic cultivation soils that slaked during mound construction, to produce very abundant dusty clay infills (arrows). PPL; scale I Zmm. (Photo by Romans and Robertson 1983.) 


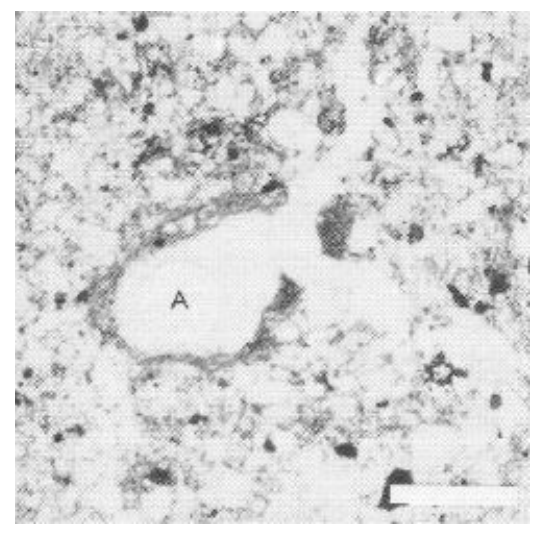

Plate 5 Kilham long barrow 1974: dctail of the Neolithic cultivated silt loam soil at around $15 \mathrm{~cm}$ depth, showing void (A) coated with very dusty clay. PPL; scale $10.2 \mathrm{~mm}$. (Dr I. W. CornWall's thin section.) Plate 7 Dehérain I986: uncultivated topsoil under grassland comprising large peds formed by wetting and drying, and biological activity. Binocular observation; scale $=2.5 \mathrm{~mm}$.

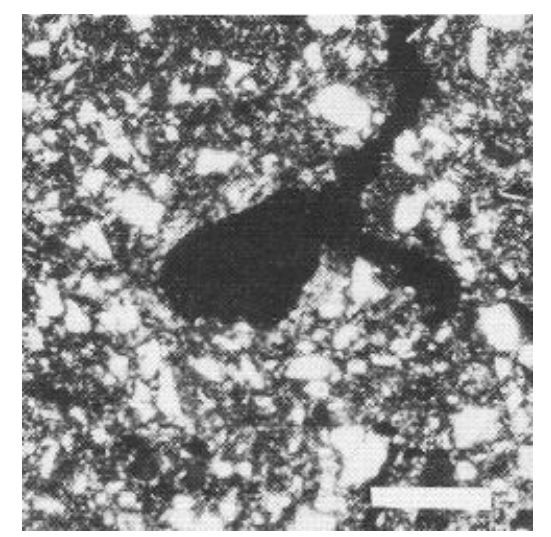

Plate 6 As Plate 5, but under XPL; note low birefringence of very dusty clay coating. Scale $=0.2 \mathrm{~mm}$.

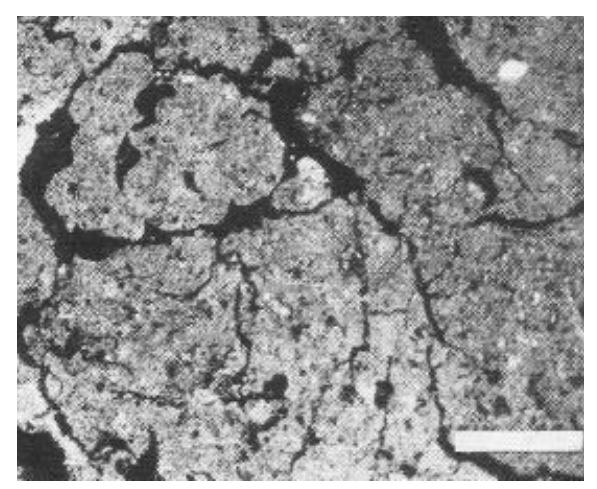

Plate 7 Dehérain 1986: uncultivated topsoil under grassland comprising large peds formed by wetting and drying and biological activity. Binocular observation; scale $=2.5 \mathrm{~mm}$. 


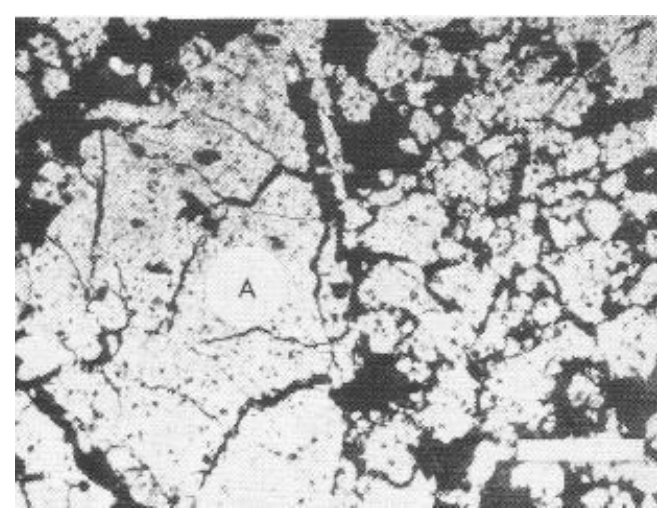

Plate 8 Dehérain I986: topsoil worked by motor-cultivator is marked by the 'explosion' of fine peds produced by tiliage impact affccting inherent weaknesses in the original large soil structures (Plate 7). Unworked relict large peds (A) also occur. Bin0Cu ar obscrvation; scale $=2.5 \mathrm{~mm}$.

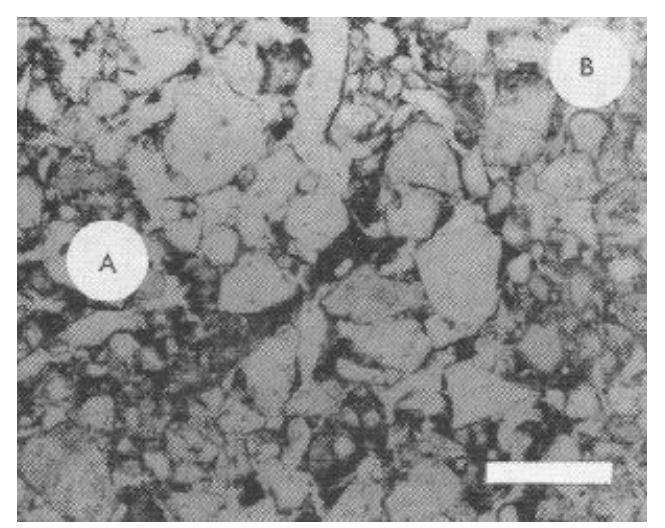

Plate 9 Phoenix Wharf 1988: junction of ardmark and uncultivated sandy soil (on the right). The cultivated soil (A) contains a dark fine fabric (Plate 10) of charred organic matter, silt and phytoliths, in contrast with thc unworked soil (B) of clcan sand grains. PPL; scale $=0.9 \mathrm{~mm}$.

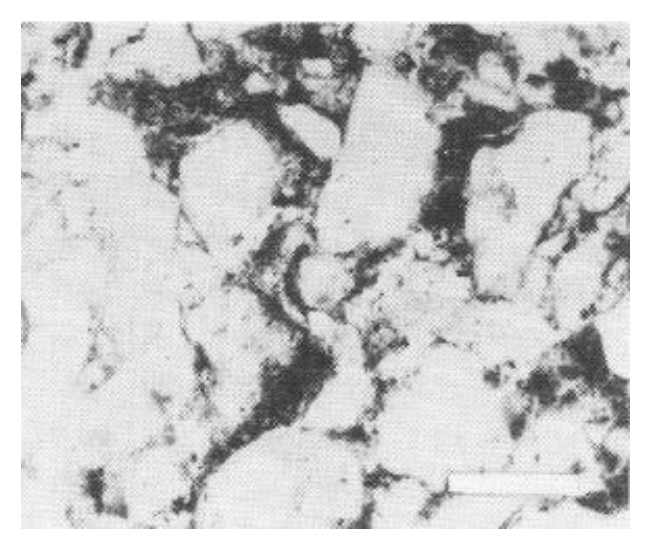

Plate I0 Phoenix Wharf 1988: detail of the edge of the ardmark showing the fine fabric loosely coating and infilling between sand grains. Dotted material is humified and charred organic matter fragments. PPL; scale $=0,05 \mathrm{~mm}$. 


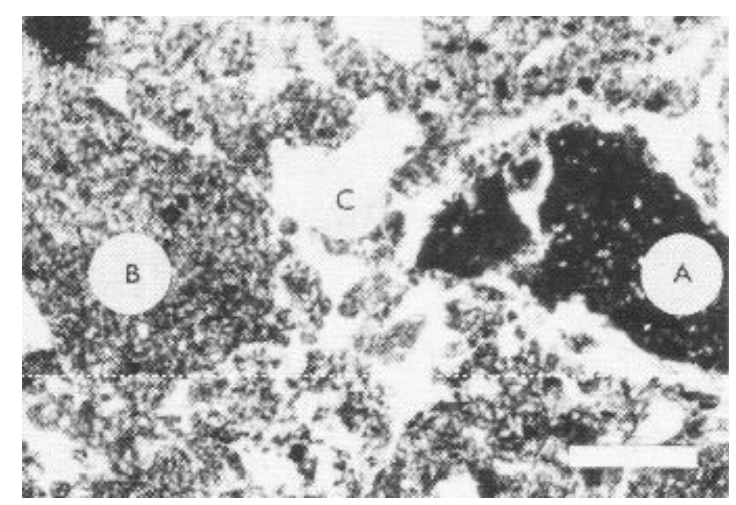

Plate 11 Ashcombc Bottom 1984: upper part of cultivation colluvium showing an eroded fragment, relic of the original argillic clay soil covcr (A), an unworked ped formed in the silt loam colluvium (B), and an open porosity of fine peds created by cultivation and the resulting enhanced biological activity (C). PPL; scale $=0.9 \mathrm{~mm}$.

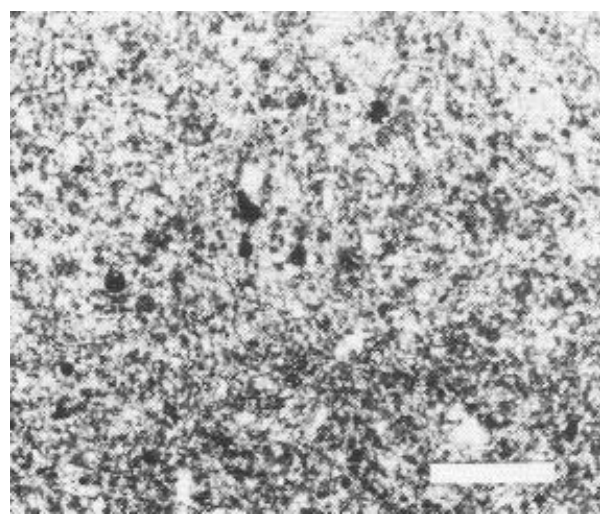

Plate I2 Ashcombe Bottom 1984: lower (prismatic) part of cultivation colluvium (8-10cm below Plate ll) showing dense packing of fine structures, and weak intercalations (dark zones) developed from minor internal slaking. PPL; scalc $=0.9 \mathrm{~mm}$. 